\title{
Preliminary evaluation of depression symptoms in adult high school students and the associated socio-demographic and environmental factors
}

\section{Przesiewowa ocena występowania objawów depresyjnych wśród dorosłej młodzieży szkót średnich oraz ich społeczno-demograficzne i środowiskowe uwarunkowania}

\author{
Grażyna Wiraszka', Martyna Głuszek-Osuch², Weronika Ptak¹, Renata B. Stępieńn \\ Institute of Nursing and Obstetrics, Faculty of Medicine and Health Science, Jan Kochanowski University, Kielce, Poland \\ Head of the Institute: Prof. Grażyna Rydzewska MD, PhD \\ ${ }^{2}$ Institute of Public Health, Faculty of Medicine and Health Sciences, Jan Kochanowski University, Kielce, Poland \\ Head of the Institute: Prof. JKU Edyta Suliga PhD
}

Key words: depression, mental health, students, early adulthood.

Słowa kluczowe: depresja, zdrowie psychiczne, młodzież szkolna, wczesna dorosłość.

\begin{abstract}
Introduction: Depression is a common mental health disorder and an important risk factor for somatic diseases. It affects various age groups, and early adulthood is associated with becoming independent and is a particularly critical period for developing depression.

Aim of the research: A screening evaluation of depression symptom incidence in young adults in the context of the sociodemographic and school-, home-, and peer-related student situation.

Material and methods: In 2018 a cross-sectional study was conducted on 149 adult high school students aged 18-20. We applied our own questionnaire together with the Beck Depression Inventory.

Results: Depression symptoms were identified in $43.6 \%$ of participants, and severe symptoms were present in $15.4 \%$. The differentiating factors included: gender $(p<0.05)$, financial situation $(p<0.001)$, self-reported health $(p<0.001)$, professional activity $(p<0.001)$, school acceptance $(p<0.01)$, school-related stress $(p<0.001)$, and home atmosphere $(p<0.05)$; but also with peer interactions: shyness $(p<0.05)$, peer acceptance $(p<0.01)$, and willingness to meet friends $(p<0.001)$.

Conclusions: The common character of occurrence of depression symptoms among the analysed school youths is an alarming phenomenon that poses a threat to their health. There is a need to enforce activities in favour of mental health of students as part of the preventive care applied in schools. There is also a need to monitor mental health during school education by using simple screening tools.
\end{abstract}

\section{Streszczenie}

Wprowadzenie: Depresja jest powszechnym zaburzeniem zdrowia psychicznego oraz istotnym czynnikiem ryzyka dla zdrowia somatycznego. Dotyczy populacji w różnym wieku, a okres wczesnej dorosłości związany z usamodzielnianiem się może stanowić szczególne zagrożenie jej wystąpieniem.

Cel pracy: Przesiewowa ocena rozpowszechnienia objawów depresyjnych wśród młodzieży w okresie wczesnej dorosłości, ich uwarunkowań społeczno-demograficznych oraz związanych z sytuacją szkolną, domową i rówieśniczą badanych uczniów. Materiał i metody: Badaniem przekrojowym przeprowadzonym w 2018 roku objęto 149 uczniów szkoły średniej regionu świętokrzyskiego w wieku 18-20 lat. Do zebrania materiału wykorzystano kwestionariusz opracowany przez autorów, a do oceny występowania objawów depresyjnych Inwentarz depresji Becka (BDI-I).

Wyniki: Objawy depresyjne zidentyfikowano u 43,6\% badanych, a znaczne ich nasilenie u 15,4\%. Czynnikami różnicującymi były: płeć $(p<0,05)$, status ekonomiczny $(p<0,001)$, samoocena zdrowia $(p<0,001)$, aktywność zarobkowa $(p<0,001)$, akceptacja szkoły $(p<0,01)$, poziom stresu szklonego $(p<0,001)$, atmosfera $\mathrm{w}$ domu $(p<0,05)$, relacje z rówieśnikami - nieśmiałość $(p<0,05)$, akceptacja przez kolegów $(p<0,01)$, otwartość na spotkania w gronie kolegów $(p<0,001)$.

Wnioski: Powszechność występowania objawów depresyjnych wśród badanej młodzieży szkolnej jest zjawiskiem niepokojącym, które stanowi zagrożenie dla zdrowia badanych. Potrzebne jest wzmocnienie działań na rzecz zdrowia psychicznego uczniów w ramach sprawowanej w szkołach opieki profilaktycznej oraz ich monitorowanie podczas nauki szkolnej z użyciem prostych narzędzi przesiewowych. 


\section{Introduction}

Depression is one of the most commonly diagnosed mental health disorders $[1,2]$ and a source of high social and economic costs [3]. It is a term commonly used to describe different experiences - from temporary and short-term mood swings, feeling unwell or 'feeling down', to sever dysfunction that can even be life-threatening $[4,5]$. In the medical sense, depression is considered to be a serious disease, systemic in nature, requiring treatment $[6,7]$. It is an overall dysfunction of the entire body, affecting mood, emotions, thinking, and physical health [4], and it reflects a more long-lasting, harmful, and serious condition that can be clinically diagnosed as depressive syndrome [8].

In recent years, an increased incidence of depression has been observed. It is assumed that the reason for this tendency is the predominant modern lifestyle, social isolation, and psychological stress [9]. According to the WHO, depression affects approximately 350 million people worldwide [1] and accounts for $4.3 \%$ of the burden of all diseases [10]. In addition, it is responsible for $7.5 \%$ of all years lived with disability (YLD) [11]. In Poland, the WOBASZ screening study was conducted, and the occurrence of depressive symptoms was identified in over a quarter of the studied population [12], while the clinical diagnosis of depression was estimated at about 20\% [13]. The EZOP epidemiological study was conducted according to the WHO methodology applying the ICD-10 and DSM-IV diagnostic criteria and included 10,000 Polish men and women aged $18-64$ years. The results suggest that depressive disorders affect about 3.6\% of adults in Poland (depression $-3.0 \%$, dysthymia $0.6 \%$ ), and about 1 million adult Poles suffer from affective disorders [14].

Depression has a negative impact on all spheres of human life [15] and is an important risk factor for suicides and somatic disorders [7, 16-18]. Also, depression increases the risk of cardiovascular events [16-19]. It is often accompanied by dyslipidaemia and diabetes [19]. In addition, it is estimated that the probability of premature death in people suffering from depression is $40-60 \%$ higher due to somatic problems that are often left undiagnosed and untreated [10].

In the past, the occurrence of depression was usually associated with mid or old age [4]. However, prevalence analysis over the last decades showed that depression is a serious problem not only for adults, but also for young adults, adolescents, or even children [2]. According to the Global Burden of Disease Study (2015), depression affects almost $6.0 \%$ of women and more than $4.0 \%$ of men in the world, aged 20-24 years, and the statistics are higher compared to younger participants (15-19 years old) [11]. On the other hand, according to the American National Institute of Mental Health (2016), major depression affects about 10.9\% of young adults aged 18-25 years [20]. Polish studies on depression and depressive symptoms have mostly been conducted on adolescents or adults with possible identification of a young adult subgroup (19-29 years old) [12, 14]. Few studies, however, have focused on the incidence of depression among adolescents. The earliest stages of adulthood are associated with achieving maturity, making life choices and becoming independent, which can be a serious psychological burden and pose a particular threat to mental health. Moreover, considering the role of depression in the aetiology of present-day lifestyle diseases, which result from exposure to long-term risk factors [16, 17, 19, $21]$, depression present in adolescents can also be a serious threat to future somatic health.

\section{Aim of the research}

Therefore, research was initiated to estimate the prevalence of depressive symptoms among adolescents and young adults, considering the socio-demographic factors as well as the school-, home-, and peerrelated situation of the participants. Understanding the magnitude of depressive symptoms in different situations may allow us to develop more effective preventive measures.

\section{Material and methods}

We carried out a cross-sectional study in March 2018 on a population of adult high school students in Włoszczów county, Świętokrzyskie Voivodeship. Our research method was a diagnostic survey, and as a research tool we used our own questionnaire together with the first version of the Beck Depression Inventory (BDI). The BDI questionnaire is a screening tool for measuring the severity of depressive symptoms. It was developed and published by Beck et al. in 1961 [22]. The questionnaire covers affective, motivational, cognitive, behavioural and somatic symptoms of depression. The Polish version of the BDI-I is a translation of the original tool, and the initial adaptation to Polish conditions was made by Parnowski and Jernajczyk [23]. The congruence between self-assessment of depression symptoms using the BDI-I and clinical diagnosis was confirmed by Bilikiewicz et al. [24]. The questionnaire consists of 21 statements, to which answers are given on a four-level scale. Then, the answers are converted into points, ranging from 0 (no symptom) to 3 (very severe symptom). Finally, the points are summed and the score falls into one of three diagnostic ranges: $0-8$ points (no symptoms), 9-18 points (moderate intensity), and over 18 points (severe symptoms) [22, 23]. The application of the BDI questionnaire in the study was dictated by the purpose of studies aimed at a screening assessment of depression and by the convenient application of the tool being of self-descriptive nature. Moreover, 
the standardised questionnaire, which is well known throughout the world and in Poland, provides the possibility of describing and comparing the studied phenomenon that is defined and understood in a uniform way.

The study included a group of 150 secondary school students attending Włoszczowa High School Complex. The inclusion criteria were age at least 18 years and informed consent to participation. After rejecting incompletely filled forms, we finally included 149 correctly completed questionnaires for statistical analysis. The study group consisted of both general education (17.4\%) and vocational education students (82.6\%). The age of the respondents ranged from 18 to 20 years (mean \pm SD: $18.7 \pm 0.73)$, and the majority of them $(47.0 \%)$ were 18 -year-olds. In the surveyed group, men (52.3\%) and urban-dwellers $(77.9 \%)$ were predominant.

\section{Statistical analysis}

The statistical analysis was performed using the IBM SPSS Statistics 25 package. To check whether the compared groups were comparable in size, as well as to test correlations between nominal variables, we used the $\chi^{2}$ test. In order to examine whether there were statistically significant differences between two independent groups, the Student's $t$-test for independent samples and its non-parametric counterpart, the MannWhitney $U$ test, were applied. For more than two subgroups, the Kruskal-Wallis test was used. The choice of the test was based on the uniformity of variance in the

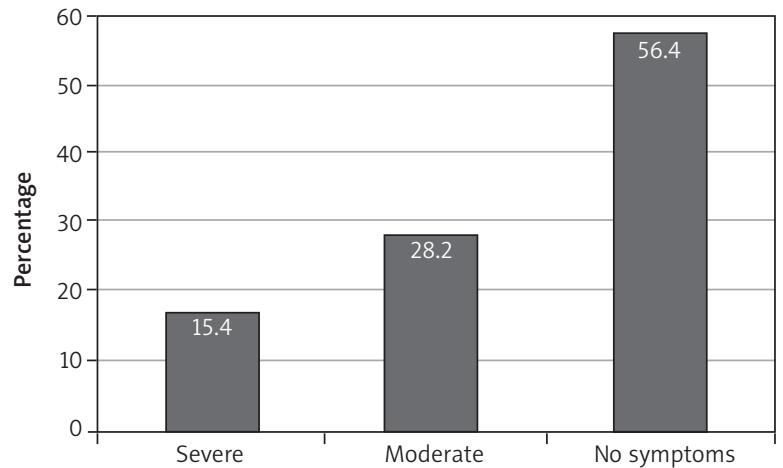

Figure 1. Severity of depression symptoms listed in BDI-I in the studied group of young adults

compared groups. Non-parametric counterparts were usually applied for different-sized groups. The statistical significance was set for a $p$-value $<0.05$.

\section{Results}

As indicated by the data shown in Figure 1, depressive symptoms were identified in $43.6 \%$ of the study group, while severe symptoms were noted for $15.4 \%$, and moderate symptoms for $28.2 \%$ of all students.

A detailed analysis of the BDI-I scale (Figure 2) indicates that, in the study group, the most troublesome symptoms included fear of the future (mean $=0.84)$, irritability/ indifference (mean $=0.82$ ), and difficulty making decisions $($ mean $=7.0)$.

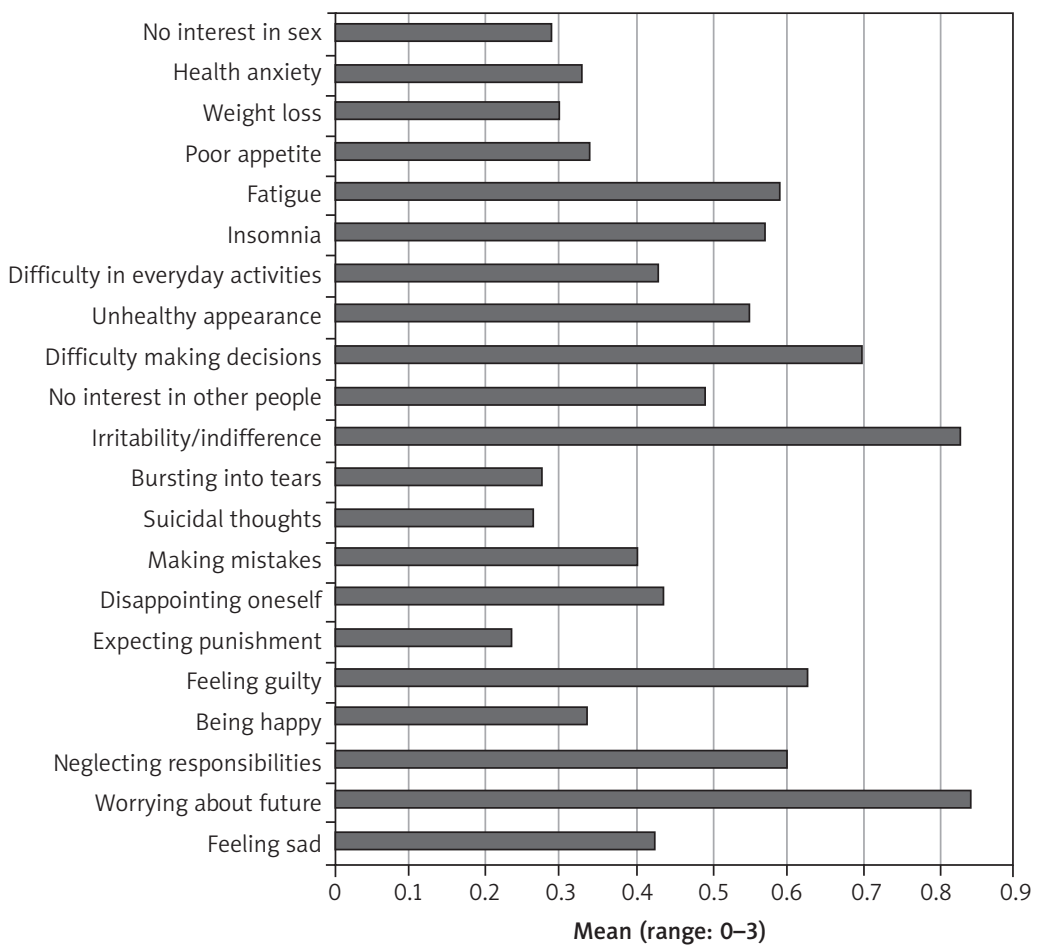

Figure 2. Detailed analysis of each BDI-I item in the studied group of young adults 
Table 1. Severity of depression symptoms in relation to socio-demographic factors and self-reported health in the studied group of young adults

\begin{tabular}{|c|c|c|c|c|c|}
\hline \multirow[t]{2}{*}{ Variable } & \multicolumn{3}{|c|}{ Severity of depression symptoms (BDI score) } & \multirow{2}{*}{$\begin{array}{l}\text { Total } \\
n(\%)\end{array}$} & \multirow[t]{2}{*}{$\lambda^{2} / p$ test } \\
\hline & $\begin{array}{c}\text { No symptoms } \\
n(\%)\end{array}$ & $\begin{array}{c}\text { Moderate } \\
n(\%)\end{array}$ & $\begin{array}{l}\text { Severe } \\
n(\%)\end{array}$ & & \\
\hline \multicolumn{5}{|l|}{ Age [year]: } & \multirow{4}{*}{$p>0.05$} \\
\hline 18 & $40(57.1)$ & $20(28.6)$ & $10(14.3)$ & $70(100.0)$ & \\
\hline 19 & $29(52.7)$ & $15(27.3)$ & $11(20.0)$ & $55(100.0)$ & \\
\hline 20 & $15(62.5)$ & 7 (29.2) & $2(8.3)$ & $24(100.0)$ & \\
\hline \multicolumn{5}{|l|}{ Sex: } & \multirow{3}{*}{$\begin{array}{c}\quad 6.05 \\
p<0.05\end{array}$} \\
\hline Female & $33(46.5)$ & $23(32.4)$ & $15(21.2)$ & $71(100.0)$ & \\
\hline Male & $51(65.4)$ & $19(24.4)$ & $8(10.3)$ & 78 (100.0) & \\
\hline \multicolumn{5}{|c|}{ Financial situation: } & \multirow{4}{*}{$\begin{array}{c}12.21 \\
p<0.01\end{array}$} \\
\hline Good & $54(70.1)$ & $18(23.4)$ & $5(6.5)$ & $77(100.0)$ & \\
\hline Average & $30(44.8)$ & $21(31.3)$ & $16(23.9)$ & $67(100.0)$ & \\
\hline Poor $^{\star}$ & - & - & - & - & \\
\hline \multicolumn{5}{|c|}{ Place of residence: } & \multirow{3}{*}{$p>0.05$} \\
\hline Urban & $17(51.5)$ & $9(27.3)$ & $7(21.2)$ & $33(100.0)$ & \\
\hline Rural & $67(57.8)$ & $33(28.4)$ & $16(13.8)$ & $78(100.0)$ & \\
\hline \multicolumn{5}{|c|}{ Self-reported health: } & \multirow{4}{*}{$\begin{array}{c}60.05 \\
p<0.001\end{array}$} \\
\hline Good & $74(66.1)$ & $30(26.8)$ & $8(7.1)$ & $112(100.0)$ & \\
\hline Average & $10(27.8)$ & $12(33.3)$ & $14(38.9)$ & $36(100.0)$ & \\
\hline Poor* & - & - & - & - & \\
\hline \multicolumn{5}{|c|}{ Type of school: } & \multirow{3}{*}{$p>0.05$} \\
\hline Vocational & $70(56.9)$ & $34(27.6)$ & 19 (15.4) & $123(100.0)$ & \\
\hline General & $14(53.8)$ & $8(30.8)$ & $4(15.4)$ & $26(100.0)$ & \\
\hline \multicolumn{5}{|c|}{ Professional activity: } & \multirow{3}{*}{$\begin{array}{c}29.26 \\
p<0.001\end{array}$} \\
\hline Active & $28(73.7)$ & $8(21.1)$ & $2(5.3)$ & 38 (100.0) & \\
\hline Inactive & $56(50.5)$ & $34(30.6)$ & $21(18.9)$ & $111(100.0)$ & \\
\hline
\end{tabular}

*Those categories were excluded from the analysis due to very small group size.

Tables 1 and 2 show the frequency of depressive symptoms divided into three categories based on their severity, with respect to the studied variables. For the socio-demographic factors (Table 1), we established a relationship between the severity of depressive symptoms and gender $(p<0.05)$, the family's wealth $(p<0.01)$, and undertaking part-time work $(p<0.001)$. We observed more severe depressive symptoms in girls, students in a poor economic situation, and professionally inactive students. We also showed the importance of selfreported health $(p<0.001)$. There were no statistically significant relationships considering the age, place of residence, and type of school $(p>0.05)$.
The severity of depressive symptoms was also different for certain factors relating to the student's school, peers, and home environment (Table 2). Relationships between the severity of depressive symptoms and the following factors were shown: school acceptance $(p<0.01)$, school-associated stress $(p<0.001)$, shyness when interacting with peers $(p<0.05)$, acceptance by colleagues $(p<0.01)$, and the atmosphere at home and the associated willingness to stay there $(p<0.001)$. Higher BDI-I scores were achieved by students who did not like school and experienced high levels of school-related stress, students who were shy when interacting with peers, those less liked by their 
Table 2. Severity of depression symptoms in relation to school-, home-, and peer-related situation in the group of young adults

\begin{tabular}{|c|c|c|c|c|c|}
\hline \multirow[t]{2}{*}{ Variable } & \multicolumn{3}{|c|}{ Severity of depression symptoms (BDI score) } & \multirow{2}{*}{$\begin{array}{l}\text { Total } \\
n(\%)\end{array}$} & \multirow[t]{2}{*}{$\lambda^{2} / p$} \\
\hline & $\begin{array}{c}\text { No symptoms } \\
n(\%)\end{array}$ & $\begin{array}{c}\text { Moderate } \\
n(\%)\end{array}$ & $\begin{array}{c}\text { Severe } \\
n(\%)\end{array}$ & & \\
\hline \multicolumn{5}{|l|}{ School acceptance: } & \multirow{4}{*}{$\begin{array}{c}44.34 \\
p<0.01\end{array}$} \\
\hline Really likes school & $64(63.4)$ & $26(25.7)$ & $11(10.9)$ & $101(100.0)$ & \\
\hline Average & $16(44.4)$ & $13(36.1)$ & $7(19.5)$ & $36(100.0)$ & \\
\hline Does not like school & $3(27.3)$ & $3(27.3)$ & $5(45.4)$ & $11(100.0)$ & \\
\hline \multicolumn{5}{|l|}{ Grades: } & \multirow{4}{*}{$p>0.05$} \\
\hline Good and very good & $45(57.0)$ & $24(30.4)$ & $10(12.7)$ & $79(100.0)$ & \\
\hline Average & $39(55.7)$ & $18(25.7)$ & $13(18.6)$ & $70(100.0)$ & \\
\hline Bad and very bad* & - & - & - & - & \\
\hline \multicolumn{5}{|l|}{ School-related stress: } & \multirow{4}{*}{$\begin{array}{c}29.06 \\
p<0.001\end{array}$} \\
\hline High & $18(31.6)$ & $22(38.6)$ & $17(29.8)$ & $57(100.0)$ & \\
\hline Moderate & $49(67.1)$ & $18(24.7)$ & $6(8.2)$ & $73(100.0)$ & \\
\hline Low & $17(89.5)$ & $2(10.5)$ & $0(0)$ & 19 (100.0) & \\
\hline \multicolumn{5}{|l|}{ Shyness: } & \multirow{4}{*}{$\begin{array}{c}10.15 \\
p<0.05\end{array}$} \\
\hline Very shy & $9(34.6)$ & $11(42.3)$ & $6(23.1)$ & $26(100.0)$ & \\
\hline Average & $34(52.3)$ & $21(32.3)$ & $10(15.4)$ & 65 (100.0) & \\
\hline Confident & $40(70.2)$ & $10(17.5)$ & $7(12.3)$ & $57(100.0)$ & \\
\hline \multicolumn{5}{|l|}{ Peer acceptance: } & \multirow{4}{*}{$\begin{array}{c}10.43 \\
p<0.01\end{array}$} \\
\hline Very much liked by others & $53(71.6)$ & $16(21.6)$ & $5(6.8)$ & $74(100.0)$ & \\
\hline Average & $30(45.5)$ & $24(36.4)$ & $12(18.2)$ & $66(100.0)$ & \\
\hline Not liked by others & - & - & - & - & \\
\hline \multicolumn{5}{|l|}{ Meeting friends: } & \multirow{4}{*}{$\begin{array}{c}21.16 \\
p<0.001\end{array}$} \\
\hline Eagerly & $55(64)$ & $22(25.6)$ & $9(10.5)$ & $86(100.0)$ & \\
\hline Average & $29(51.8)$ & $18(32.1)$ & $9(16.1)$ & $56(100.0)$ & \\
\hline Unwillingly & $0(0)$ & $2(28.6)$ & $5(71.4)$ & $7(100.0)$ & \\
\hline \multicolumn{5}{|l|}{ Home atmosphere: } & \multirow{4}{*}{$\begin{array}{c}23.6 \\
p<0.001\end{array}$} \\
\hline Likes to stay home & $63(64.3)$ & $28(28.6)$ & $7(7.1)$ & $98(100.0)$ & \\
\hline Average & $20(51.3)$ & $9(23.1)$ & $10(25.6)$ & $39(100.0)$ & \\
\hline Does not like to stay home & $1(0.3)$ & $5(41.7)$ & $6(50.0)$ & $12(100.0)$ & \\
\hline \multicolumn{5}{|l|}{ Siblings: } & \multirow{4}{*}{$p>0.05$} \\
\hline None & $8(66.7)$ & $1(8.3)$ & $3(25.0)$ & $12(100.0)$ & \\
\hline 1 (brother or sister) & $36(60.0)$ & $15(25.0)$ & $9(15.0)$ & $60(100.0)$ & \\
\hline$>1$ & $40(51.9)$ & $26(33.8)$ & $11(14.3)$ & 77 (100.0) & \\
\hline
\end{tabular}

colleagues, as well as by students who did not feel very happy staying at home. However, the scores were not affected by school grades, nor the number of siblings $(p>0.05)$.

The relationships between the severity of depressive symptoms and socio-demographic or studentrelated variables are presented in Tables 1 and 2 and have been confirmed by statistically significant differences between mean BDI-I scores, as shown in Figures 3 and 4 . However, no statistically significant difference was noted only for willingness to interact with peers, although more active students scored lower, on average, compared to those less active (mean $=8.21$ and mean $=10.58$, respectively, $p>0.05$ ). 


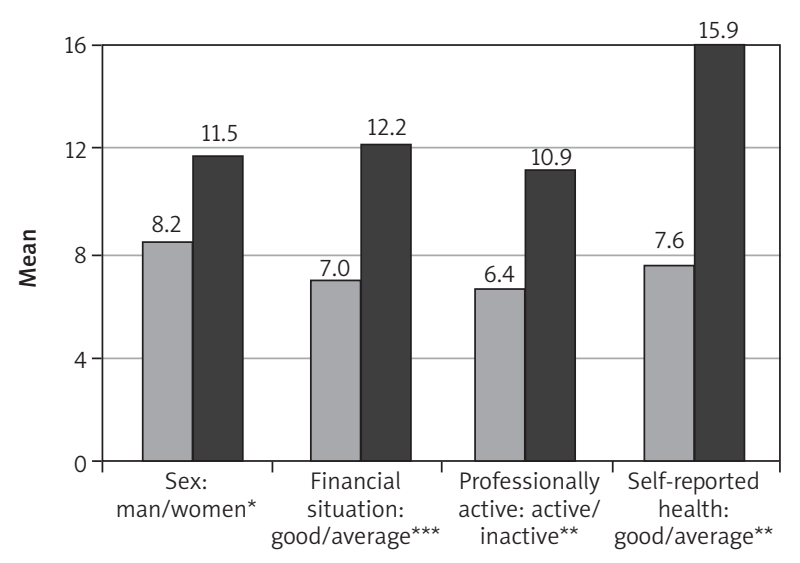

Figure 3. Mean BDI-I scores in the studied group of young adults, socio-demographic factors, and self-reported health (Student's $t$-test/Mann-Whitney $U$ test, ${ }^{*} p<0.05$, $\left.{ }^{* *} p<0.01 ;{ }^{* * *} p<0.001\right)$

\section{Discussion}

Mood disorders are common health problems [1, $2,10,12,14]$ recognised not only in adults but also in children and adolescents [4, 2, 25]. People suffering from mood disorders show impaired functioning in many areas of life [15]. According to the literature, the onset of depression often occurs in adolescence or early adulthood, and young people are more and more commonly afflicted [4]. By the age of 18 years, as many as $20 \%$ of teenagers have had at least one depressive episode [25]. The highest incidence and prevalence rates are reported for older adolescents and young adults over 20 years old [4].

Our results confirm a high prevalence of depressive disorders even among the youngest group of adults aged 18-20 years. Depressive symptoms were identified in as many as $43.6 \%$ of the study group $53.6 \%$ of women and $34.7 \%$ of men, respectively), while severe symptoms were reported by $15.4 \%$. Similar, although slightly lower, scores were also reported in the study involving 1993 17-year-old high school students in Cracow. Depression symptoms listed in the Beck Inventory were presented by $41.2 \%$ of girls and $22.7 \%$ of boys, respectively [26]. High scores were also reported in the group of 279 girls aged $13-25$ years, involving students of Lublin universities $(n=222)$ and junior high school students from Świętokrzyskie Voivodeship $(n=57)$. Depressive symptoms in that study were identified in $44.2 \%$ of the respondents [27]. On the other hand, lower scores were reported among physiotherapy students in Wrocław aged 22-25 years. Depression symptoms occurred in $31.6 \%$ of women and $19.5 \%$ of men, respectively [28]. Lower frequency of depressive symptoms was also observed in students of the Medical University of Gdansk, where depressive symptoms were evaluated using the HADS scale. The mean age was $20.0 \pm 0.9$ years, and abnormal results

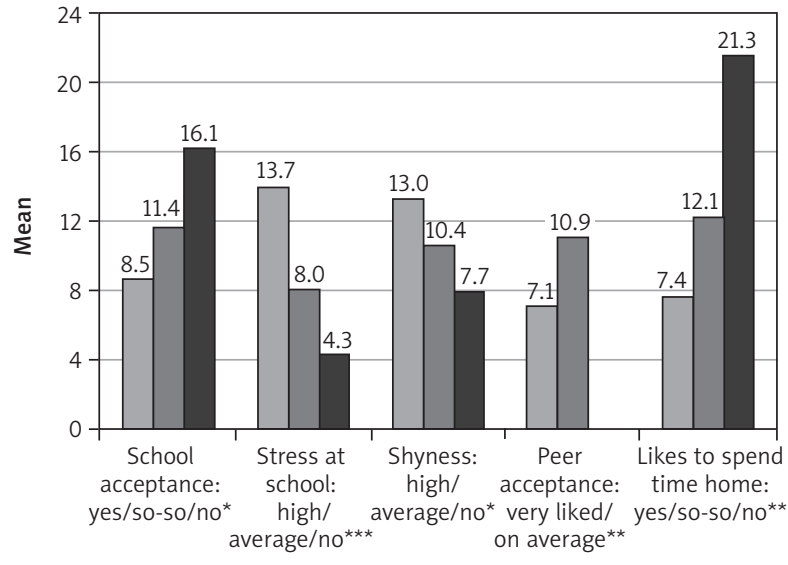

Figure 4. Mean BDI-I scores in the studied group of young adults in relation to school-, peer-, and home-related situation (Kruskal-Walls/Student's t-test; ${ }^{*} p<0.05$; ${ }^{* *} p<0.001$; $\left.{ }^{* * *} p<0.001\right)$

(> 7 points) were present in $19.7 \%$ of women and $14.5 \%$ of men, respectively [29]. Our results are slightly higher compared to data from other screening studies. In the WOBASZ study on an adult Polish population, depressive symptoms affected approximately a quarter of the individuals [12]. In a study involving almost 2000 American students, depressive symptoms were found in $33.5 \%$ of women and $22.4 \%$ of men, respectively [30]. More severe symptoms in our study may relate to the region in which the study was conducted. According to the EZOP report, Świętokrzyskie Voivodeship ranks second (following Łódzkie Voivodeship) in terms of mental health disorders in Poland [14]. It can also result from the nature of early adulthood, when teenagers are faced with taking responsibility for their own lives and have to make life choices affecting their future lives. It is supported by the observation that in our study, the most commonly reported problem was worrying about the future.

Among the socio-demographic variables, the most influential factors affecting the severity of depressive symptoms in the studied group were gender $(p<0.05)$ and the economic status of the parents $(p<0.01)$. Significantly more severe depressive symptoms were presented by girls and students in a poor financial situation. The association of gender with depressive symptoms has also been reported in other studies on adult populations, both globally and in Poland [10-12, 14, 30, 31]. Kuehner reported that women suffer from depression twice as often as men [31]. In Poland, the WOBASZ study showed that depressive symptoms are present in $24 \%$ of men and in 34\% of women, respectively [12]. Also, depression was more common among adult Polish women enrolled in the EZOP study, compared to men [14]. Another study conducted on a similar age group including 200 Greek 18-year-olds showed 
more severe depressive symptoms in girls compared to boys [32]. Gender differences were also confirmed by the Global Burden of Disease Study, and this trend applies to all regions of the world, as well as to all age groups [11].

The literature indicates that people affected by depression function poorly at work, at school, and in the family [1]. In our study, the relationship between selfreported emotional condition of the respondents and their school-, home-, and peer-related situation was also demonstrated. More severe depressive symptoms were noted for students disliking school $(p<0.01)$ and those with a negative atmosphere at home, who did not like staying there $(p<0.001)$. A higher level of depressive symptoms was also noted in students who were shy when interacting with their peers $(p<0.05)$, less popular and with fewer friends $(p<0.01)$, and less likely to meet with their friends $(p<0.001)$. However, it is difficult to unambiguously assess the direction of those correlations. Depression itself can deteriorate social functioning $[1,15]$, but also adverse environmental conditions [10] or social isolation [9] can provoke depressive symptoms. Jonkers et al. point out that the creation of appropriate environmental conditions and training in dealing with negative stimuli can significantly reduce the incidence of depression [33].

In the studied group, an important school-related factor associated with more severe depressive symptoms was psychological stress $(p<0.001)$. The relationship between stress and the severity of symptoms in adolescents and young adults was also reported by other authors. A high level of stress in adolescents was associated with many depressive symptoms among Thai students aged 15-19 years [34], as well as Polish students aged 19-39 years. Stress also correlated with greater severity of depressive symptoms listed in the Beck Inventory, as well as with insomnia [35]. Our results support the view that stress is a factor increasing the risk of depressive disorders $[9,36,37]$. The role of stress is emphasised by theories relating depression to chronic inflammation, when the disease is seen as 'a chronic cold' of the body in response to stressful events [38]. Dysfunction of the hypothalamic-pituitary-adrenal (HPA) axis, also referred to as the stress axis, can be observed in $50-75 \%$ of patients diagnosed with major depression [36].

In light of our study and the available literature, the problem of increasing incidence of depression seems to be very serious, both in the general population as well as among young adults, especially during early adulthood. That is why it is extremely important to implement effective policies promoting mental health, addressing all students, including the youngest ones, but also why we need to monitor mental health in students of varying ages using simple screening tools. Early detection of symptoms could give the opportunity to undertake individual preven- tive measures. This seems extremely important, especially considering data showing that less than half of people affected by mental health disorders receive treatment, one of the barriers to successful care being inaccurate evaluation of presenting symptoms [1].

However, the achieved results, although they are quite similar to the reports from other studies, should be approached with prudence. The presented study has its limitations. Those limitations include the narrow area of research and the negligible testing used in the assessment. One has to remember that the applied research tool is of a screening nature. Thus, the achieved results do not stand for the occurrence of depression of clinical nature.

\section{Conclusions}

The common character of occurrence of depression symptoms among the analysed school youths is an alarming phenomenon that poses a threat to their health. There is a need to enforce activities in favour of mental health of students as part of the preventive care applied at schools. There is also a need for monitoring mental health during school education by using simple screening tools. It seems that it is necessary to have continuous education, both for medical professionals as well as for teachers and parents, within the scope of early identification of depression symptoms and within the scope of efficient support, as well as to raise the caregivers' awareness concerning the significance of the school environment, home, and peers in the shaping of psychological comfort.

\section{Conflict of interest}

The authors declare no conflict of interest.

\section{References}

1. Fact sheets. Depression. World Health Organization. https://www.who.int/news-room/factsheets/detail/depression (4.02.2019).

2. Płatek AE, Szymański FM, Filipiak KJ, Ozierański K, Kotkowski M, Tymińska A, Kowalik R, Karpiński G, Opolski G, RACER Steering Committee and Investigators. Częstość występowania zaburzeń depresyjnych w grupie zawodowych kierowców - subanaliza epidemiologiczna badania RACER. Psychiatr Pol 2016; 50: 859-871.

3. DiLuca M, Olesen J. The cost of braindiseases: a burdenor a challenge? Neuron 2014; 82: 1205-1208.

4. Hammen C. Depresja. Trzebiatowska M (ed. Polish edition). Gdańskie Wydawnictwo Psychologiczne, Gdańsk 2006.

5. Pużyński S. Depresje i zaburzenia afektywne. Wydawnictwo PZWL, Warsaw 2009.

6. Kokoszka A. Współzachorowalność zaburzeń depresyjnych i nerwicowych - jej znaczenie w teorii i praktyce lekarskiej. Przew Lek 2003; 8: 87-91.

7. Narodowy Program Ochrony Zdrowia Psychicznego na lata 2017-2022. Załącznik do Rozporządzenia Rady Ministrów z dnia 8 lutego 2017 r. Dziennik Ustaw, Poz. 458. 
8. Dietrich D, Neumann B. Depresja nie jest przeznaczeniem. Wydawnictwo WAM, Kraków 2007.

9. Puri BK, Treasaden IH. Zaburzenia nastroju (afektywne), samobójstwa i parasamobójstwa. In: Psychiatria. Rybakowski J, Robakowski F (eds. Polish edition). Wydawnictwo Urban \& Partner, Wrocław 2014; 167-188.

10. Mental Health Action Plan 2013-2020. WHO, Geneva 2013. https://apps.who.int/iris/bitstream/handle/10665/ 89966/9789241506021_eng.pdf?sequence=1. Available at: 04.02.2019.

11. Depression and Other Common Mental Disorders: Global Health Estimates. Geneva: World Health Organization; 2017. Licence: CC BY-NC-SA 3.0 IGO.

12. Piwoński J, Piwońska A, Głuszek J, Bielecki W, Pająk A, Kozakiewicz K, Wyrzykowski B, Rywik S. Ocena częstości występowania niskiego poziomu wsparcia społecznego oraz objawów depresji w populacji polskiej. Wyniki programu WOBASZ. Kardiol Pol 2005; 63 (supl. 4): 1-4.

13. Araszkiewicz A, Piekarska A, Dróżdż W. Zaburzenia depresyjne i lękowe u pacjentów podstawowej opieki zdrowotnej. Dysk Depr 2001; 16: 2-19.

14. Moskalewicz J, Kiejna A, Wojtyniak B. Kondycja psychiczna mieszkańców Polski. Raport z badań: Epidemiologia zaburzeń psychiatrycznych i dostęp do psychiatrycznej opieki zdrowotnej - EZOP Polska. Instytut Psychiatrii i Neurologii, Warszawa 2012.

15. Kessler RC, Bromet EJ. The epidemiology of depression across cultures. Annu Rev Public Health 2013; 34: 119-138.

16. Nicholson A, Kuper H, Hemingway H. Depression as an aetiologic and prognostic factor in coronary heart disease: a meta-analysis of 6362 events among 146538 participants in 54 observational studies. Eur Heart J 2006; 27: 2763-2774.

17. Hare DL, Toukhsati SR, Johansson P, Jaarsma T. Depression and cardiovascular disease: a clinical review. Eur Heart J 2014; 35: 1365-1372.

18. Bielejewska A, Bociek A, Ślusarczyk R, Sadowski M. Cardiac disorders with psychosomatic background. Stud Med 2017; 33: 316-320.

19. Wiltink J, Beutel ME, Till Y, Ojeda FM, Wild PS, Münzel T. Blankenberg S, Michal M. Prevalence of distress, comorbid conditions and well being in the general population. J Affect Disord 2011; 130: 429-437.

20. Mental Illness. Major Depression. National Institute of Mental Health, USA. https://www.nimh.nih.gov/health/ statistics/mental-illness.shtml (Accessed at: 20.12.2018).

21. Piepoli MF, Hoes AW, Agewall S, Albus C, Brotons C, Catapano AL, Cooney MT, Corra U, Cosyns B, Deaton C, Graham I, Hall MS, Hobbs FDR, Lochen ML, Löllgen H, Marques-Vidal P, Perk J, Prescott E, Redon J, Richter DJ, Sattar N, Smulders Y, Tiberi M, van der Worp HB, van Dis I, Verschuren WMM, Binno S. 2016 European Guidelines on cardiovascular disease prevention in clinical practice. Eur Heart J 2016; 37: 2315-2381.

22. Beck AT, Ward CH, Mendelson M, Mock J, Erbaugh J. An inventory for measuring depression. Arch Gen Psychiatry 1961; 4: 561-571.

23. Parnowski T, Jernajczyk W. Inwentarz Depresji Becka w ocenie nastroju osób zdrowych i chorych na choroby afektywne. Psychiatr Pol 1977; 11: 417-421.

24. Bilikiewicz A, Pużyński S, Rybakowski J, Wciórka J. Psychiatria. Tom 1 - Podstawy psychiatrii. Wydawnictwo Medyczne Urban \& Partner, Wrocław 2002.
25. Kołodziejek M. Depresja u dzieci i młodzieży: podstawy teoretyczne, psychoterapia poznawczo-behawioralna. Psychoterapia 2008; 2: 15-33.

26. Modrzejewska R, Bomba J. Rozpowszechnienie zaburzeń psychicznych i używania substancji psychoaktywnych w populacji 17-letniej młodzieży wielkomiejskiej. Psychiatr Pol 2010; XLIV: 579-592.

27. Makara-Studzińska M, Podstawka D, Królik L. Wsparcie emocjonalne a poziom lęku i depresji wśród młodych kobiet stosujących diety odchudzające. Hygeia Public Health 2013; 48: 340-345.

28. Jaworska L, Morawska N, Morga P, Szczepańska-Gieracha J. Analiza częstości występowania objawów depresyjnych wśród studentów Wydziału Fizjoterapii Akademii Wychowania Fizycznego we Wrocławiu w kontekście planów zawodowych. Fizjoterapia 2014; 22: 10-22.

29. Marek K, Białoń P, Wichowicz H, Melloch H, Nitka-Siemińska H. Przesiewowa ocena rozpowszechnienia objawów depresyjnych i lękowych wśród studentów Akademii Medycznej w Gdańsku. Psychiatria 2005; 2: 217-224.

30. Wattick RA, Hagedorn RL, Olfert MD. Relationship between diet and mental health in a young adult appalachian college population. Nutrients 2018; 10: 957.

31. Kuehner C. Why is depression more common among women than among men? Lancet Psychiatry 2017; 4: 146-158.

32. Matziou V, Hatira K, Perdikaris P, Zachos I, Mellou K, Bakoula C. Weight status and depressive symptoms in 18 year-old Greek adolescents. Pediatr Rep 2010; 2: e16: 51-54.

33. Jonkers CCM, Lamers F, Bosma H, Metsemakers JFM. The effectiveness of a minimal psychological intervention on self-management beliefs and behaviors in depressed chronically ill elderly persons: a randomized trial. Int Psychogeriatr 2012; 24: 288-297.

34. Maritta V, Ruthaychonnee S, Minna A. Survey of adolescents' stress in school life in Thailand: implications for school health. J Child Health Care 2017; 21: 222-230.

35. Nowak G, Żelazko A, Nowak D, Waliczek M, Pawlas K. Zależność między zachowaniami zdrowotnymi a poziomem stresu i występowaniem bezsenności oraz depresji u studentów zdrowia publicznego. Piel Zdr Publ 2015; 5: 231-238.

36. Hansson PB, Murison R, Lund A, Hammar A. Cognitive functioning and cortisol profiles in first episode major depression. Scand J Psychol 2015; 56: 379-383.

37. Finnell JE, Wood SK. Neuroinflammation at the interface of depression and cardiovascular disease: Evidence from rodent models of social stress. Neurobiol Stress 2016; 4: $1-14$.

38. Gałecki P, Talarowska M. Neurodevelopmental theory of depression. Prog Neuropsychopharmacol Biol Psychiatry 2018; 80: 267-272.

\section{Address for correspondence}

Grażyna R. Wiraszka PhD

Department of Oncology and Nursing Oncology

Institute of Nursing and Obstetrics

Faculty of Medicine and Health Science

Jan Kochanowski University

al. IX Wieków Kielc 19, 25-317 Kielce, Poland

Phone: +48 503072060

E-mail:wiraszka@ujk.edu.pl 